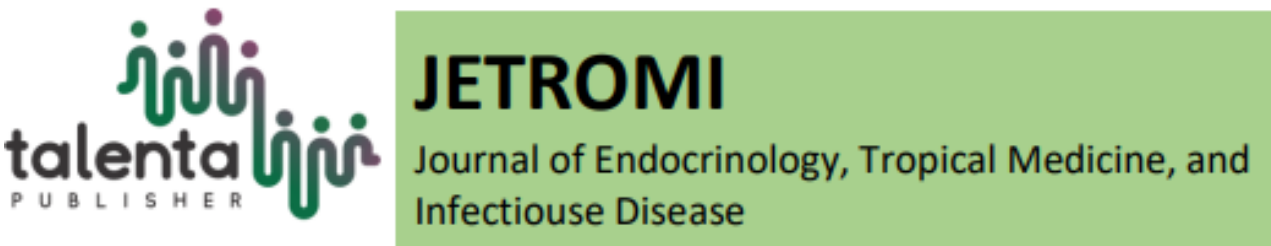

\title{
Relationship Between Staging and Carcinoembryonic Antigen Serum Levels in Colorectal Cancer Patients
}

\section{Chandra Agusrly, Taufik Sungkar, and Gontar Alamsyah Siregar}

Division of Gastroenterology of Department of Internal Medicine, Faculty of Medicine, Universitas Sumatera Utara

\begin{abstract}
Background: The staging can be used as one of the prognostic factors providing a clinical picture of the patient in the future in colorectal cancer patient. In addition, carcinoembryonic antigen (CEA) as tumor markers can determine the commonly used diagnosis and prognosis of colorectal cancer. Objective: The aims study was to investigate the relationship of the staging and carcinoembryonic antigen serum levels in colorectal cancer patients. Methods. This was an analytical study with a cross-sectional design. The sample used was colorectal cancer patients at H. Adam Malik General Hospital, Medan from January 2016 to December 2018. As many as 52 subject study who met the inclusion and exclusion criteria. The Kruskal-Wallis test was used to determine relationship between staging and CEA serum levels. Results: The median value of carcinoembryonic antigen levels in Stage I, II, III, and IV group was ( $2.74 \mathrm{ng} / \mathrm{ml}$ vs $6.16 \mathrm{ng} / \mathrm{ml}$ vs $2.52 \mathrm{ng} / \mathrm{ml}$, vs $26.87 \mathrm{ng} / \mathrm{ml}$; p=0.003) respectively. Conclusion: There was relationship between staging and carcinoembryonic antigen serum levels in colorectal cancer patient.
\end{abstract}

Keyword: Colorectal cancer, Carcinoembryonic Antigen, Staging tumor

\begin{abstract}
Abstrak. Pendahuluan: Stadium dapat digunakan sebagai salah satu faktor prognostik yang memberikan gambaran klinis pasien di masa depan pada pasien kanker kolorektal. Di samping itu, kadar Antigen Carcinoembryonic (CEA) sebagai penanda tumor, dapat menentukan diagnosis dan prognosis kanker kolorektal yang umum digunakan. Tujuan: Penelitian ini bertujuan untuk menyelidiki hubungan antara stadium dengan kadar CEA pada pasien kanker kolorektal. Metode: Penelitian ini merupakan penelitian analitik dengan desain potong lintang. Sampel yang digunakan adalah pasien kanker kolorektal di Rumah Sakit Umum H. Adam Malik, Medan periode Januari 2016-Desember 2018. Sebanyak 52 subjek penelitian yang memenuhi kriteria inklusi dan eksklusi. Tes Kruskal-Wallis digunakan untuk menentukan hubungan antara stadium dan kadar serum CEA. Hasil: Nilai median kadar serum CEA pada stadium I, II, III, dan IV adalah masing-masing (2.74 $\mathrm{ng} / \mathrm{ml} v \mathrm{~s} 6.16$ $\mathrm{ng} / \mathrm{ml}$ vs $2.52 \mathrm{ng} / \mathrm{ml}$, vs $26.87 \mathrm{ng} / \mathrm{ml} ; \mathrm{p}=0.003$ ). Kesimpulan: Terdapat hubungan antara stadium dan kadar serum CEA pada pasien kanker kolorektal.
\end{abstract}

Kata Kunci: Kanker kolorektal, Carcioembryonic Antigen, Stadium tumor

Received 10 May 2020 | Revised 25 August 2020| Accepted 28 August 2020

\footnotetext{
*Corresponding author at: Faculty of Medicine, Universitas Sumatera Utara, Jl. Dr. T. Mansur No. 5, Medan 20115, Medan, Indonesia

E-mail address: Chandra_agusrly@yahoo.com
} 


\section{Introduction}

Colorectal cancer is a malignant condition arising from abnormal growth of tissue cells originating from the large intestine and/or rectum.[1] Increasing mortality (880 thousand) in the general population has caused colorectal cancer as the second leading cause of cancer deaths worldwide.[2] In Indonesia, the incidence of colorectal cancer was ranked fourth with an incidence rate of 12.1 per 100,000 and rank fifth as the cause of death after breast, cervical, lung, and liver cancer. The mortality rate caused by colorectal cancer reaches 6.9 per 100,000 of all cancers.[3] Many factors that contribute to colorectal cancer such as sex, age, race, obesity, alcohol consumption, and red meat, and smoking are risk factors for colorectal cancer. [4]

American Joint Committee for Cancer Executives (AJCC) classified colorectal cancer into four stages namely Stage I, II (A, B, and C), III (A, B, and C), IV (A and B).[5] The higher the number of stages suffered, the smaller of survival rate. [6] Early detection in the early stages of colorectal cancer becomes very important cause can be a prognostic factor in determining survival rate of colorectal cancer patients. This is what underlies the need for screening test.

Carcinoembryonic antigen (CEA) serum is the most commonly used biomarker in laboratory tests for screening, diagnosis, prognostication, and monitoring of treatment and recurrence in patients with colorectal cancer. Seventy-two point four percent (72.4\%) of colorectal cancer patients have elevated levels of CEA. [7-9]. In Medan, there is still no previous studies on the relationship between staging and CEA levels in a patient with colorectal cancer. Therefore, the author would like to research the relationship between staging and CEA levels in colorectal cancer patients suffers in H. Adam Malik General Hospital, Medan.

\section{Methods}

This was an analytical study with cross-sectional design. The study was carried out at H. Adam Malik General Hospital, Medan. The study subjects were patients who were diagnosed with colorectal cancer colonoscopy and histopathology examinations from January 2016-December 2018.

The inclusion criteria in this study were patients diagnosed with colorectal cancer, there are laboratory data for examination of CEA and tumor stages. Meanwhile, the exclusion criteria include incomplete data and patients suffering from other comorbid diseases such as hepatitis and hyperthyroidism. The following data were collected from medical records: age, gender, CEA level, tumor location, and staging.

Statistical analysis was performed using SPSS version 22.0, with $95 \%$ confident interval. To examine relationship between staging and CEA serum levels was tested by Kruskal-Wallis test 
and followed by the Mann-Whitney test to determine the difference between carcinoembryonic antigen serum levels in various staging groups.

\section{Results}

Based on the inclusion and exclusion criteria obtained 52 of 71 patient's data that becomes the sample of study. The characteristic of the colorectal cancer patients, gender, age, site of cancer, and staging, are presented in Table 1. Table 2 presents the Kruskal-Wallis test. The test showed that a significant result $(\mathrm{p}=0.003)$ was obtained between the staging with CEA levels. The post hoc test was used to determinate which group has a difference. Stage I and IV, II and IV, III and IV showed that significant results, $\mathrm{p}=0.001,0.017,0.021$ respectively. Meanwhile, the others group was statistically not significant (table 3 )

Table 1 The Characterictics of Subjects $(n=52)$

\begin{tabular}{cl}
\hline \multicolumn{1}{c}{ Variable } & \multicolumn{1}{c}{$\mathrm{n}(\%)$} \\
\hline Age (years) & \\
$\geq 50$ & $33(63.5 \%)$ \\
$\quad<50$ & $19(36.5 \%)$ \\
Gender & \\
Male & $(28) 5.8 \%$ \\
Female & $(24) 46.2 \%$ \\
Site of cancer & \\
Right-sided & $5(9.6 \%)$ \\
Left-sided & $21(40.4 \%)$ \\
Rectum & $26(50 \%)$ \\
Stage & $24(46.2 \%)$ \\
I & $9(17.3 \%)$ \\
II & $4(7.7 \%)$ \\
III & $15(28.8 \%)$ \\
IV &
\end{tabular}

Table 2 Relationship Between Staging and CEA Serum Levels

\begin{tabular}{cccccc}
\hline Variable & $\begin{array}{c}\text { Stage I } \\
(\mathrm{n}=24)\end{array}$ & $\begin{array}{c}\text { Stage II } \\
(\mathrm{n}=9)\end{array}$ & $\begin{array}{c}\text { Stage III } \\
(\mathrm{n}=4)\end{array}$ & $\begin{array}{c}\text { Stage IV } \\
(\mathrm{n}=15)\end{array}$ & $P^{* *}$ \\
\hline $\begin{array}{c}\text { CEA } \\
\text { levels } \\
(\mathrm{ng} / \mathrm{ml}) *\end{array}$ & $2.7(1.04-1968.9)$ & $6.16(0.98-1500)$ & $2.52(1.8-22.2)$ & $26.87(4.2-1759)$ & 0.003 \\
\hline
\end{tabular}

* Values are median (minimun-maximum); **Kruskal-Wallis Test $(\mathrm{p}<0.01)$ 
Table 3 Comparison of CEA Serum Levels Among The Colorectal Cancer Stages

\begin{tabular}{lcc}
\hline Staging Groups & CEA level $(\mathrm{ng} / \mathrm{ml})^{*}$ & $P^{* *}$ \\
\hline I vs II & $2.74(1.04-1968.9)$ vs $6.16(0.98-1500)$ & 0.352 \\
I vs III & $2.74(1.04-1968.9)$ vs $2.52(1.8-22.2)$ & 0.896 \\
I vs IV & $2.74(1.04-1968.9)$ vs $26.87(4.2-1759)$ & 0.001 \\
II vs III & $6.16(0.98-1500)$ vs $2.52(1.8-22.2)$ & 0.537 \\
II vs IV & $6.16(0.98-1500)$ vs $26.87(4.2-1759)$ & 0.017 \\
& $2.52(1.8-22.2)$ vs $26.87(4.2-1759)$ & 0.021 \\
III vs IV &
\end{tabular}

*Values are median(minimun-maximum); ${ }^{* *}$ Mann-Whitney test

\section{Discussion}

CEA is a cancer tumor marker and is predominantly used clinically in conditions with colorectal cancer. It is an oncofetal protein that is normally present during fetal life but may be present in healthy adults in low concentrations.[10]

Among the 52 subjects, patients with colorectal cancer were dominated by male $(53,8 \%)$ than female $(46,2 \%)$. The male gender has the risk of colorectal cancer occurrence than in female. It is suspected that this is due to the tendency of men to prefer diets that are high in red meat and its processed products as well as a higher alcohol consumption and smoking habit and a greater chance of visceral fat accumulation associated with an increased risk of colorectal cancer.[11-12]

The most frequent site of cancer in colorectal cancer patients was the rectum by $60 \%$ (26 cases), as compared with others site. Yusra et al [13] also obtained a similar result showing that the most common site of colorectal cancer was rectum by $55.9 \%$. However, it is different from a research by Gunasekaran et al [14] stating that the most frequent site of colorectal cancer was colon by $40.5 \%$.

Our study showed that increasing CEA levels serum with increasing stages of colorectal cancer and the relationship was statistically significant. Similar results were found by Barata[8], showing that the end of stage of colorectal cancer produced more higher CEA levels compare the others. This is in contrast of previous study, who stated that there was no statistically significant relationship between the CEA levels and staging of colorectal cancer patient's.[15]

The CEA levels may be within normal limits in the majority of patients with colorectal cancer. Increased CEA pre-operative learning outcomes associated with the bad prognosis post-surgery, 
besides of course the affected by staging and grading of tumor histopathology.[16] The mechanism of CEA in increasing the incidence of advanced stages in colorectal cancer is still not fully understood yet, but according to the previous study, CEA can activate Kupfer cells in the liver to induce the overexpression of cytokines and change the liver microenvironment to allow circulating colorectal tumor cells to survive in the liver.[17]

\section{Conclusion}

There was significant results between staging and CEA serum levels in colorectal cancer patients.

\section{REFERENCES}

[1] American Cancer Society. "Colorectal cancer facts \& figures 2017-2019". Atlanta: American Cancer Society; 2017.

[2] GLOBOCAN (2018). "Colorectal cancer.," 2018. Available: https://gco.iarc.fr/today/data/factsheets/cancers/10_8_9-Colorectum-factsheet.pdf. Accessed: 21 April 2019

[3] GLOBOCAN (2018). "Estimated age-standardized incidence rates (World) in 2018, all cancers, both sexes, all ages", 2018.

[4] Gandomani HS, Yousefi SM, Aghajani M, Mohammadian-Hafshejani A, Tarazoj AA, Pouyesh V, et al. "Colorectal cancer in the world: incidence, mortality and risk factors". Biomed Res Ther, vol. 4, pp.1656-1675. 2017.

[5] AJCC, "Colon and Rectum," in: American Joint Committee On Cancer (Ajcc) Cancer Staging Manual, 7th ed., S. B. Edge, D. R. Byrd, C. C. Compton, A. G. Fritz, F. L. Greene, and A. Trotti, Eds. Chicago: Springer New York Dordrecht Heidelberg London, 2010, pp. 143-164.

[6] KEMENKES RI. Panduan Penatalaksanaan Kanker kolorektal. 2015.

[7] F. R. Permana, B. P. Budiono, and H. Farida, "Hubungan Kadar Carcinoembryonic Antigen ( Cea ) Dan Albumin Serum Dengan Lokasi Kanker Kolorektal," JKD, vol. 5, no. 4, pp. 808-816, 2016.

[8] I. G. N. P. N. Y. Barata, M. A. D. Sueta, and M. S. Adnyana, "Hubungan Antara Kadar Carcinoembryonic Antigen (Cea) Dan Stadium Kanker Kolorektal Di Rsup Sanglah Tahun 2016-2017’. E-Jurnal Medika, vol. 7, pp. 1-5. 2018.

[9] S. Jain, M. R. Pincus, M. H. Bluth, R. A. Mcpherson, W. B. Bowne, and P. Lee, "Diagnosis And Management Of Cancer Using Serologic And Other Body Fluid Markers," in Henry's Clinical Diagnosis and Management by Laboratory Methods, 23rd ed., Elsevier Inc., 2019, pp. 1432-1449.

[10] D. E. Sanford, S. P. Goedegebuure, and T. J. Eberlein, "Tumor Biology and Tumor Markers," in Sabiston Textbook of Surgery, 20th ed., Philadelphia: Elsevier Inc., 2019, pp. 676-704.

[11] M. R. Dianty, I. M. Nur, Widyanti. "Karakteristik pasien kanker kolorektal di bagian patologi anatomi rumah sakit al-islam bandung januari 2012-desember 
2017", in Seminar Penelitian Sivitas Akademika Unisba, Bandung 2018: Prosiding Pendidikan Dokter; 2018 Agustus; Jawa Barat, Bandung, D. Ahmadi, I. Karya, A. Nurrahman, Wawang, M. K Dewi, S. Diari S, Eds. Bandung: UNISBA; 2018. pp. 131-40.

[12] A. White, L. Ironmonger, R. J. C. Steele, N. Ormiston-Smith, C. Crawford, and A. Seims, "A review of sex-related differences in colorectal cancer incidence, screening uptake, routes to diagnosis, cancer stage and survival in the UK," $B M C$ Cancer, vol. 18, pp. 906, 2018.

[13] C. A. Yusra, I. Virghiandy, and V. Novianry, "Gambaran Pasien Kanker Kolorektal Di Rsud Dr. Soedarso Pontianak Periode Tahun 2006 - 2010," J. Mhs. Fak. Kedokt. UNTAN, vol. 2, no. 1, pp. 1-25, 2013.

[14] V. Gunasekaran, N. P. Ekawati, and I. W. J. Sumadi, "Karakteristik klinikopatologi karsinoma kolorektal di RSUP Sanglah , Bali , Indonesia tahun 2013-2017," Intisari Sains Medis, vol. 10, no. 3, pp. 552-556, 2019.

[15] O. Topdagi and A. Timuroglu, "Evaluation of the relationship between carcinoembryonic antigen and TNM stage in colorectal cancer," Eurasian J. Med., vol. 50, pp. 96-98, 2018.

[16] C. Wei, Q. Liu, S. Tan, and Y. Jiang, "Association between carcinoembryonic antigen, carbohydrate antigen 19-9 and body mass index in colorectal cancer patients," Mol. Clin. Oncol., vol. 1, pp. 879-86, 2013.

[17] J. H. Lee and S.-W. Lee, "The Roles of Carcinoembryonic Antigen in Liver Metastasis and Therapeutic Approaches," Gastroenterol. Res. Pract., vol. 2017, pp. 1-11, 2017. 